\title{
Anna ZĄBKOWICZ
}

Instytut Nauk Ekonomicznych PAN, Warszawa

\section{Stosunki między państwem i biznesem a wzrost gospodarki}

\section{Wbrew konwencji}

Sprawa wzrostu gospodarczego, który zapewnia większy bochenek do

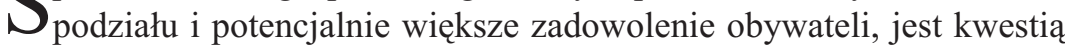
przetrwania dla polityków zawsze i bez względu na ich orientację polityczną. Po to, aby zrealizować ten cel, państwo potrzebuje dostępu do kapitału. Komunistyczne państwa w Europie Środkowo-Wschodniej próbowały rozwiązać problem zacofania, przejmując prywatny kapitał i opierając rozwój gospodarczy na własności państwowej. Teraz, kiedy po transformacji systemu kraje naszego regionu dołączyły do gospodarek opartych na własności prywatnej, logicznym sposobem zapewnienia sobie przez rządy dostępu do kapitału wydaje się współpraca z jego właścicielami. W jakich warunkach współdziałanie między rządem i biznesem może pobudzić tempo wzrostu gospodarczego? Pytanie to natychmiast budzi wątpliwości większości ekonomistów i adeptów nauk politycznych. Patrząc z perspektywy nauk politycznych, biznes czyli kapitał zajmuje uprzywilejowaną pozycję w każdej kapitalistycznej gospodarce i wykorzystuje ją prędzej do osiagnięcia partykularnych korzyści niż w imię rozwoju gospodarki narodowej. Ekonomiści podjęli ów sposób rozumowania, rozwijając m.in. ten temat dzięki przeniesieniu do domeny nauk politycznych analitycznych narzędzi swojej nauki. Teoria wyboru publicznego (public choice) w interesującej nas sprawie mówi, że zbiorowe działania biznesu skierowane do państwa często przybierają charakter lobbyingu na rzecz interwencji, która psuje mechanizm rynku i zmniejsza efektywność alokacji zasobów (tzw. rent seeking).

To stanowisko ma szansę i w Polsce stać się poglądem podzielanym przez większość wykształconych ludzi w miarę jak rozwijać się będą badania nad korporacjonizmem, a w szczególności nad systemem repre- 
zentacji biznesu ${ }^{1}$. Podręczniki dla studentów i książki studiowane przez profesjonalistów zawierają bowiem głównie idee pokrewne głównemu nurtowi, takie jak między innymi szkoła publicznego wyboru. Tymczasem całkiem nowe doświadczenie stało się w ostatnich dekadach ubiegłego wieku inspiracją dla niektórych uczonych amerykańskich i europejskich do zajęcia mniej sceptycznego stanowiska wobec postawionego wyżej pytania. Mowa o rewelacyjnym powojennym wzroście nowo-uprzemysłowionych krajów z innego kręgu kulturowego - w Azji Południowo-Wschodniej ${ }^{2}$. Historia sukcesu tych krajów zdaje się świadczyć za tym, że oparte na współpracy stosunki między rządem i biznesem nie zawsze ulegają degeneracji, przekształcając się w poszukiwanie dochodów rentowych (rent seeking). W tym artykule przedstawimy próbę spojrzenia na stosunki państwo-biznes z perspektywy innej niż konwencjonalne podejście, podzielane przez główny nurt nauk politycznych i ekonomiczną szkołę publicznego wyboru.

Stosunki między państwem i biznesem oraz między państwem i pracą najemną leżą u podstaw wielkich wizji państwa. Pojmowanie państwa jako ,agenta dobrobytu” (welfare state) zakłada koalicję ze światem pracy. Wizja państwa jako spiritus movens rozwoju gospodarczego (developmental state) opiera się na stosunkach państwo-biznes z tego prostego powodu, że biznesmeni są właścicielami kapitału potrzebnego do wzrostu produktu krajowego. Obraz państwa wszechpotężnego i nienasyconego, stworzony przez szkołę publicznego wyboru (państwo-Lewiatan Jamesa Buchanana i państwo jako Mafia według Mancura Olsona), zawiera w tle również stosunki z biznesem, który cośkolwiek z tej potęgi i przychodów chce uszczknąć.

Stosownie do podzielanych wartości oraz poczynionych założeń, współdziałanie państwa i biznesu oceniane jest z różnych perspektyw.

1 W Polsce spiritus movens badań nad strategią negocjacyjną i korporacjonizmem, czyli systemem reprezentacji interesów głównych grup społecznych, jest Jerzy Hausner (1994). Przedmiotem tych badań były interesy, które zostały wyartykułowane w związku z rozpadem sektora przedsiębiorstw państwowych oraz związane z tym zmiany na rynku pracy (patrz Hausner, Wojtyna, 1993; Evolution ..., 1995). Jak dotąd badania korporacjonizmu w Polsce nie objęły, jak się wydaje, organizacji biznesu.

${ }^{2}$ Chodzi o niespełna 10 krajów, które w latach 50. i 60. ubiegłego wieku szybko zwiększyły udział przemysłu w dochodzie narodowym, zmniejszając jednocześnie lukę, jaka dzieliła je od najbardziej rozwiniętych krajów świata. Najbardziej spektakularny sukces osiagnęły w tej grupie Korea Południowa i Tajwan. Japonia jako jedyna dołączyła do krajów wiodących w gospodarce światowej. 
W teorii publicznego wyboru państwo jawi się jako machina przymusu, który rozprzestrzenia się stosownie do indywidualnych interesów polityków i biurokracji rządowej. Państwo ma tendencję do nadużywania siły, poszukując ciaggle nowych źródeł dochodów. Taka wizja jest konsekwencją przyjęcia założenia charakterystycznego dla głównego nurtu ekonomii, zgodnie z którym racjonalne jednostki podążają za własnym interesem i - w warunkach niedostatku zasobów - konkurują między sobą. Współpraca podejmowana tam, gdzie wzajemna wymiana obiecuje korzyści, nie zmienia konkurencyjnego nastawienia ludzi i konfrontacyjnego charakteru modelu stosunków między nimi. W świecie tej teorii rząd jest postrzegany bardziej jako przeciwnik we współzawodnictwie o maksymalizację własnych dochodów niż jako życzliwy dostarczyciel dóbr publicznych. Im potężniejsze jest państwo, tym większa pokusa dla biznesu, aby przenieść konkurencję z dziedziny gospodarki do dziedziny polityki w celu przejęcia renty, czyli dochodu wyprodukowanego przez kogo innego i redystrybuowanego przez państwo. W konsekwencji tych nieproduktywnych działań koalicji na rzecz podziału dochodu zaburzeniu ulega system wkładu i nagrody, charakteryzujący zdrową gospodarkę rynkową. Zbiorowe działania biznesu w tym kontekście są oceniane jako pasożytnicze i niepożądane. Wobec tego zaleca się nakładanie ograniczeń, czyli tworzenie barier instytucjonalnych, aby zapobiec takiemu nieproduktywnemu współdziałaniu biznesu i państwa.

Badacze procesów uprzemysłowienia w Azji Południowo-Wschodniej i innych krajach rozwijających się (patrz m.in. Nelson 1989; Weiss, Hobson 1995) postrzegają państwo przede wszystkim jako ,agenta rozwoju" i starają się ustalić warunki, w których kapitał posiadany przez biznes może zostać zaangażowany w rozwój gospodarki narodowej. Przyjmują, że motorem działań państwa są raczej wspólne cele polityczne niż indywidualne interesy polityków i urzędników, co dobrze objaśnia następujący cytat: [Potrzeba rozwoju gospodarczego w kraju rozwijającym się] „wynika z pragnienia, aby osiagnąć pełny ludzki status, uczestnicząc w cywilizacji przemysłowej, w której sam udział umożliwia narodowi i jednostce wymuszenie na innych równego traktowania. Niezdolność do uczestniczenia w niej czyni naród militarnie bezsilnym wobec sąsiadów, administracyjnie niezdolnym do kontrolowania swych własnych obywateli i kulturowo nieprzygotowanym do posługiwania się międzynarodowym językiem" (cytat Ernesta Gellnera za Johnson, 1992, s. 24-25). Ponieważ do urzeczywistnienia tej cywilizacyjnej misji niezbędny jest wzrost gospodarczy, państwo rozwojowe skupia się na celach ekonomicznych, pod- 
czas gdy w wizji szkoły wyboru publicznego najważniejsze jest zdobycie i używanie władzy, a w wizji państwa dobrobytu liczą się prawa socjalne. Doświadczenie krajów nowo-uprzemysłowionych podpowiada, że współdziałanie rządu z biznesem przyczynia się raczej do wzrostu gospodarczego niż jemu szkodzi. Wobec tego poszukuje się argumentów na rzecz produktywnej współpracy raczej niż sposobów na budowanie instytucjonalnych barier między państwem i biznesem (patrz Haggard, Maxfield, Schneider, 1997).

Ideologia wpływa na ocenę i dobór argumentów, ale zdaje się nie mieć wpływu na instytucjonalną strukturę władzy. Instytucjonalne ramy, w których podejmuje się decyzje o polityce gospodarczej i inne decyzje państwowe, wydają się podobne bez względu na to, z jaką misją identyfikuje się dane państwo i jaki ma charakter system polityczny ${ }^{3}$. Innymi słowy, reżim i demokracja może się chwiać, ale okrzepły sposób zarządzania państwem pozostaje. Rdzeń tej struktury stanowi rząd, który w procesie decyzyjnym ma silniejszą pozycję niż parlament (szczególnie w krajach „doganiających”, takich jak Polska ${ }^{4}$ ). Kanały dostępu do rządu otwarte są dla uprzywilejowanych, którymi zwykle są grupy interesu reprezentujące sektory strategiczne dla gospodarki i polityki. Wszędzie, nawet w reżimach autorytarnych, powiązania „kolesiów” (old boys networks), czyli osobiste związki między ludźmi nauki, interesu, biurokratami i politykami, stanowią nieformalne kanały wpływów. Struktury państwowe w takim układzie trwają bez względu na to, czy państwu przyświeca ideologia neoliberalna, socjalistyczna czy też misja rozwoju.

Strukturę władzy można porównać do mostu, a proces polityki gospodarczej - do gry strategicznej. Dwie armie: państwo i biznes stoją na swoich pozycjach na przeciwległych brzegach. Most umożliwia dostęp do brzegu przeciwnika. Może go wykorzystać biznes do podboju rządu, jeśli ten jest słaby. Takie stosunki siły, jak się wydaje, panują w USA, a także wielu krajach mniej rozwiniętych ${ }^{5}$. Ale most może także umożliwić dostęp rządowym biurokratom do biznesu w celu wywierania wpływu na

3 Mamy tu na myśli efektywną zdolność podejmowania decyzji w odróżnieniu od formalnego uprawnienia.

${ }^{4}$ Inne współczesne przykłady krajów, gdzie większość dyskusji i decyzji rodzi się poza parlamentem stanowią Japonia, Chile, Argentyna, Brazylia, Korea.

W krajach mniej rozwiniętych możliwości państwa często krępują sojusze lokalnych bonzów i zagranicznych interesów. Takie zjawiska jak nepotyzm, klientelizm, korupcja czy działalność mafijna są przejawami słabości państwa. 
jego organizacje i siatki, jeżeli są oni dostatecznie sprawni, tak jak to było w Japonii. Trudno jest przewidzieć skutki przekroczenia mostu przez jedną ze stron, chyba że wiemy więcej o możliwościach i cechach graczy. Innymi słowy, nie należy poddawać interpretacji stosunków między państwem i biznesem bez uprzedniego rozeznania wewnętrznej struktury zarówno jednego jak drugiego (patrz Evans 1997; Haggard, Maxfield, Schneider 1997).

\section{Wlaściwości skutecznego państwa}

Różne charakterystyki polityków gospodarczych są kluczem do rozbieżności między neoliberalnymi poglądami na interwencję państwa w gospodarkę i alternatywnym punktem widzenia, który zajmuje nas przede wszystkim w tym artykule. Zgodnie $\mathrm{z}$ behawioralnym pojmowaniem racjonalności, przejętym przez szkołę wyboru publicznego i inne neoliberalne teorie, ludzie dążą do maksymalizacji korzyści, zatem nie ma powodu, aby politycy i biurokraci kierowali się innymi motywami niż indywidualny interes - ekonomiczny lub polityczny. Ich zachowaniem rządzi logika przewidywanych (także materialnych) konsekwencji. Dlatego w razie potrzeby dla korzyści mogą oszukiwać, a ich działalność niekoniecznie przyczynia się do wspólnego dobra. Z punktu widzenia szkoły wyboru publicznego, wysiłki biurokratów rządowych idą w kierunku maksymalizacji budżetu, jakim mogą dysponować, rozrostu sektora publicznego i centralizacji decyzji (Downs 1957; Niskanen 1971).

Przyjęcie, że państwo i jego ludzie kierują się misją rozwojową, z kolei mieści się w weberowskiej perspektywie, która uwzględnia, oprócz behawioralnej racjonalności, również wartości i uczucia. Indywidualna użyteczność bądź korzyść nie jest jedyną pożądaną konsekwencją; wybory dokonywane są również w oparciu o społecznie akceptowane normy i zasady. Motywy wyborów, a w konsekwencji - zachowania polityków gospodarczych, są nie tylko materialistyczne, ale także altruistyczne. W książce Maxa Webera Etyka protestancka a duch kapitalizmu biurokracja państwowa jest postrzegana jako służba publiczna.

Jakość biurokracji ma decydujące znaczenie dla charakteru państwa, gdyż biurokraci z reguły stanowią trzon instytucjonalnej struktury władzy. Rząd jest często postrzegany przez badaczy jako raczej tymczasowy zespół czołowych przywódców politycznych, natomiast państwo - jako raczej stały personel i biurokracja sektora publicznego (np. Haggard, 
Maxfield, Schneider 1997). Biurokraci są zawsze formalnie podporządkowani politykom. Jednak, ponieważ czas zatrudnienia na stanowisku urzędnika ministerialnego jest $\mathrm{z}$ reguły dłuższy niż ministra, ten pierwszy zwykle posiada więcej unikalnej szczegółowej wiedzy, co stanowi jego przewagę, dzięki której potencjalnie może powodować swoim przełożonym - politykiem. Rola biurokratów zwykle nie ogranicza się do kompetencji regulacyjnych, ale obejmuje także formułowanie polityki gospodarczej. W rezultacie, chociaż władza formalnie przypisana jest do domeny polityków (rząd, parlament), faktycznie należy do biurokratów ${ }^{6}$. Tak jest przynajmniej w przypadku państw określanych jako silne.

Wśród badaczy państwa rozwojowego panuje konsensus co do tego, że jego skuteczność wymaga, aby biurokracja kierująca ekonomicznym rozwojem była chroniona przed wszystkimi grupami interesów z wyjątkiem tych najpotężniejszych, po to, aby była w stanie ustalać i osiagać długookresowe priorytety, inicjować działania i kontrolować, czy przebiegają zgodnie z jej intencjami (Johnson 1992; Weiss, Hobson 1995). Krótko mówiąc, od takiego odseparowania (insulation) zależy jej autonomia. Polega ono, jak wyjaśniają Weiss i Hobson (1995), na zachowaniu dziedzin polityki gospodarczej, które nie są poddawane negocjacjom, na zachowaniu marginesu, gdzie politycy gospodarczy znajdują się poza zasięgiem specjalnych próśb, nacisków lub krótkowzrocznych żądań tej czy innej grupy interesów, a ich programy nie cierpią z powodu dramatycznych zmian wywołanych decyzjami elektoratu. Odseparowanie jest potrzebne, gdyż - jak pisze Johnson (1992, s. 44): „System w którym pełna gama grup nacisku i interesu funkcjonujących w nowoczesnym otwartym społeczeństwie ma skuteczny dostęp do rządu, z pewnością nie osiagnie rozwoju gospodarczego, przynajmniej pod oficjalnymi auspicjami, bez względu na to jakich by innych wartości nie realizował".

Jednak koncepcje, jak osiągnać taką separację biurokracji rządowej od grup interesów, są bardzo różne. Niektórzy uczeni wyrażają przekonanie, że zmowa i korupcja są mniej prawdopodobne, jeżeli biurokraci przypominają typ weberowski (Schneider, Maxfield 1997, s. 15). Po przekroczeniu metaforycznego mostu przez biznes biurokracja tego typu unika podboju (albo raczej niszczącego wpływu), chroniona przez wewnętrzne procedury. Najważniejsze z nich to merytokratyczne kry-

${ }^{6}$ Język angielski umożliwia istotne rozróżnienie. Władza formalna określana jest jako ,authority”, moc podejmowania decyzji, czyli władza faktyczna nazywa się ,power". 
teria angażu i awansu, zatrudnienie na długi termin, rozsądne wynagrodzenie i związany z zawodem prestiż. Im bardziej biurokracja w danym kraju zbliża się do tego weberowskiego wzorca, tym bardziej prawdopodobne, że jej stosunki z biznesem przyniosą pozytywne rezultaty.

Według szkoły publicznego wyboru, politycy i biurokraci powinni być powstrzymywani w swoim dążeniu do indywidualnych korzyści przez nakładanie barier zewnętrznych. Podczas gdy w tradycyjnych analizach przyjmuje się, że celem rządu jest osiagnięcie pewnego dochodu w ramach, które wyznacza wzgląd na efektywność i sprawiedliwość, adepci szkoły publicznego wyboru widzą raczej państwo w roli Lewiatana, które poszukuje coraz to nowych źródeł dochodu. W rękach takiego państwa możność zaciągania długów i kreacji pieniądza staje się wyjątkowo niebezpiecznym uprawnieniem. Konstytucyjne ograniczenia deficytu budżetowego oraz prawne ograniczenie możliwości drukowania pieniędzy są przejawem starań obywateli, aby ograniczyć owe możliwości zwiększania dochodów przez rządową biurokrację do pewnych rozmiarów (Brennan, Buchanan 1980). Procedury zewnętrzne dla biurokracji, określone przez prawo (np. procedury budżetowe lub kompetencje banku centralnego decydujące dla jego niezależności od rządu) stanowią ograniczenia uznaniowej władzy polityków i urzędników państwowych. Zawężona i podzielona domena państwa stanowi dla biznesu mniejszą pokusę poszukiwania dochodów rentowych.

Zgodnie z alternatywnym do szkoły publicznego wyboru punktem widzenia, separacja nie może oznaczać izolacji, lecz przez wzgląd na sprawność powinna być dopełniona zinstytucjonalizowaną współpracą między państwową biurokracją i bizenesem (Weiss, Hobson 1995; Evans 1997). Instytucjonalne kanały stałych negocjacji i renegocjacji celów oraz polityki gospodarczej sprawiają, że państwo jest wbudowane w społeczeństwo. Po to jednak, by współpraca państwa $\mathrm{z}$ otoczeniem była skuteczna, niezbędna jest wewnętrzna spójność biurokracji państwowej. Evans (1997) w sposób następujący rozwija ideę ,wbudowanej autonomii” (emebedded autonomy). Zarówno autonomia bez ukorzenienia jak ukorzenienie bez autonomii mogą przynieść niepożądane efekty ${ }^{7}$. Sukces współpracy nie

Kraje Ameryki Łacińskiej dostarczają przykładów. Regułą jest tam słabe państwo w sieci powiązań i zdezintegrowane społeczeństwo, w którym dominuje konflikt raczej niż współpraca (Kochanowicz 1994). Interesujące, że chilijski eksperyment $\mathrm{z}$ lat 70. ubiegłego wieku mający na celu wzmocnienie autonomii państwa za pomocą prawie idealnego odseparowania polityków gospodarczych pod parasolem autorytar- 
jest kwestią wyboru: albo odseparowana i zwarta biurokracja, albo bliskie związki z sektorem prywatnym; i to i to jest konieczne, ,albo” powinno być zastapione przez „i”. Evans powołuje się na przykład japońskiego ministerstwa gospodarki: ,autonomia MITI pozwalała mu zajmować się problemami, na jakie napotykało zbiorowe działanie prywatnego kapitału i pomagać mu w znalezieniu rozwiązania, którego samodzielne poszukiwanie wiele by kosztowało. Gdyby MITI nie było zdolne do formułowania celów i nie mogłoby liczyć na zaangażowanie swoich urzędników $\mathrm{w}$ ich urzeczywistnienie, miałoby bardzo mało do zaoferowania prywatnemu sektorowi” (Evans 1997, s. 74). Z drugiej strony bez rozbudowanej siatki kontaktów z biznesem biurokraci z MITI nie byliby w stanie zdobywać wiedzy insidera, która pomagała im w skutecznym osiaganiu celów, czyli w umacnianiu własnej autonomii. Bez wystarczająco spójnej struktury administracyjnej, związki z sektorem prywatnym przeobrażają biurokrację w narzędzie prywatnych korzyści, jeśli jednak aparat państwowy jest dostatecznie zwarty, związki te przestają być synonimem podboju. W tej sytuacji państwo jest w stanie ukierunkować pościg za zyskiem na zwiększające wydajność inwestycje. Zwartość biurokracji jest zatem sposobem na powstrzymanie działań biznesu w celu przejęcia renty i wydaje się podstawowym warunkiem wbudowanego w społeczeństwo i zarazem sprawnego państwa, który jednakże nie został dość precyzyjnie określony.

Nawet, jeżeli warunek spójności administracji ekonomicznej został spełniony, podstawową sprawą jest odseparowanie biurokracji od drugiego zbiorowego aktora - od polityków. Tu problem dla merytokratycznych biurokratów jest większy, gdyż politycy mają legalnie usankcjonowany wpływ na biurokrację. Weberowskie bodźce kariery mogą stanowić część pancerza chroniącego przed korupcją urzędników, ale nie polityków, których kariera na wybieralnym stanowisku zależy w dużym stopniu od subsydiowania kampanii wyborczej przez biznes. $\mathrm{Z}$ tego powodu zwierzchnicy biurokratów nie mogą zostać instytucjonalnie odseparowani od partykularnych interesów grup nacisku wywodzących się z biznesu.

W tej kwestii warto znów zrobić dygresję, odwołując się do doświadczenia Japonii. Japoński parlament ma niewielki wpływ na formę ustaw i działa raczej jako ratyfikator projektów, opracowanych przez rządową biurokrację. A w rządzie tylko stanowiska ministrów zajmowane są przez

nego reżimu również się nie sprawdził. Autonomia, którą cieszyła się technokratyczna ekipa pozwalała na podręcznikowe i dogmatyczne zachowania, które przyczyniły się do wyjątkowo głębokiego kryzysu społecznego. 
polityków; pozostała część ministerialnego aparatu, wiceministrów nie wyłączając, składa się z apolitycznych urzędników. Jak zauważa Johnson (1992, s. 35): ,istnieje rozbieżność między konstytucyjnym i faktycznym umiejscowieniem suwerenności, co jest tak wyraźne, że Japończycy wymyślili terminy, aby móc o niej dyskutować”. Mianowicie, jest podział: władzy formalnej (authority) i władzy decyzyjnej (power); tego co zewnętrzne, widoczne gołym okiem i tego co wewnętrzne, ukryte; panowania i rządzenia; przy czym pierwsze człony tych par należą do domeny polityków, a drugie - do domeny biurokratów. Zdaniem Johnsona taka rozbieżność przyczynia się do realizacji rozwojowej misji państwa.

Złożywszy wymienione właściwości razem, otrzymujemy obraz państwa, które jest zdolne do planowania i pobudzania wzrostu gospodarki w produktywnej koalicji z biznesem. Patrząc nań widzimy biurokrację sektora publicznego, autonomiczną, wbudowaną w społeczeństwo za pomocą różnych instytucji i zarazem odseparowaną od biznesu dzięki zasadom awansu, przy tym wszystkim - stosunkowo niezależną od polityków.

\section{Struktura i organizacja biznesu}

Biznes można określać na różne sposoby i według różnych aspektów można przedstawiać jego wpływ na rządy. Tu posłużymy się klasyfikacją według Haggarda, Maxfielda i Schneidera (1997, s. 38-57), wskazującą na pięć aspektów. Jak pokazują wspomniani autorzy, oprócz zbiorowego działania $w$ ramach swoich organizacji, biznes wywiera wpływ na politykę gospodarczą z przyczyn strukturalnych.

Biznes nie musi być zorganizowany, aby odgrywać rolę w polityce gospodarczej; wystarczy siła wynikająca z jego charakteru i struktury. $\mathrm{Na}$ najwyższym stopniu agregacji biznes reprezentuje kapital, czyli jeden z czynników produkcji. Ponieważ poziom inwestycji decyduje o wzroście gospodarczym, ograniczeniem decyzji rządu w gospodarce mieszanej są zawsze spodziewane reakcje sektora prywatnego. W rezultacie, jak to wyraził Albert O. Hirschman, kapitał głosuje dwa razy: raz za pośrednictwem zorganizowanego nacisku na polityków, drugi raz za pomocą decyzji inwestycyjnych. Zabieganie o zagranicznych inwestorów i kredytodawców oraz obawa przed ucieczką kapitału częściowo wyjaśnia przyczyny, dla których dość powszechnie współczesne państwa wycofują się z zarządzania i ograniczają kontrolowanie gospodarki oraz stosują politykę makroekonomiczą o zbliżonym charakterze. Właściciele płynnych aktywów 
starają się o jak największe zyski i w związku z tym doceniają gwarancje praw własności, niskie opodatkowanie, korzystne regulacje i niską inflację. Jeśli te preferencje nie zostaną zaspokojone za pomocą odpowiedniej polityki gospodarczej, wówczas prywatna kontrola nad decyzjami inwestycyjnymi oraz ruchliwość kapitału mogą wywrzeć opaczny wpływ na wzrost gospodarki.

Wyniki gospodarki zależą od wrażliwości biznesu vel kapitału na politykę gospodarczą. Nawet wtedy, gdy rząd robi ustępstwa w odniesieniu do opodatkowania, regulacji itp., inwestorzy mogą nie zareagować. W tej sytuacji kluczową sprawą wydaje się wiarygodność rządu. Prywatne podmioty mogą się obawiać, że względy polityczne odwiodą rząd od wcześniejszych zamiarów stworzenia środowiska sprzyjającego biznesowi. Pewnym rozwiązaniem problemu wiarygodności jest wprowadzenie reguł w polityce gospodarczej i instytucjonalnych ograniczeń uznaniowego działania, o których była mowa wcześniej ${ }^{8}$. Oprócz działań „wiążących ręce" rządowi, wiarygodności mogą służyć różne fora, na których prowadzi się konsultacje i negocjacje między rządem, biznesem i (czasami) światem pracy. Stwarzając okazje do powtarzalnych kontaktów i oddziaływań, instytucje takie wydłużają horyzonty i sprzyjają zaufaniu. Jako przykład mogą służyć japońskie instytucje doradcze (deliberation councils) oraz pakty społeczne i praktyka regularnych spotkań w celu rozwiązania konkretnych problemów polityki gospodarczej (concertaci'on) w niektórych krajach Ameryki Łacińskiej. ${ }^{9}$. Dostęp biznesu do rządu i ustalone reguły gry przyczyniają się do wiarygodności rządu. Wówczas, w odpowiedzi na rządowe ustępstwa biznes z większym prawdopodobieństwem powściagnie ucieczkę kapitału lub zintensyfikuje inwestycje. Stałe i przejrzyste reguły gry, wzajemne zaufanie sprawiają, że kapitaliści i rząd mogą lepiej współpracować na rzecz wzrostu gospodarczego.

Autonomię rządów ogranicza nie tylko prywatna własność kapitału i innych zasobów, ale również rywalizacja interesów różnych sektorów biznesu. Chociaż ochrona praw własności i sprzyjający biznesowi klimat leżą w ich wspólnym interesie, kapitaliści mogą mieć zarazem rozbieżne

8 Na przykład, prawne ograniczenie wpływu rządu na decyzje banku centralnego można postrzegać jako pierwszy krok ku uwiarygodnieniu polityki monetarnej. Wprowadzenie tzw. reguły monetarnej, która oznacza deklarację banku centralnego, że tempo wzrostu podaży pieniądza w długim okresie będzie stałe, jest następnym krokiem.

9 Chodzi o doświadczenie Chile, Brazylii i Meksyku na przełomie lat 80. i 90. ubiegłego wieku. 
interesy, jeżeli chodzi o konkretną politykę gospodarczą rządu ${ }^{10}$. Te różnice zwykle wynikają z rozproszenia aktywności gospodarczej między różne sektory. Ogólnie panuje przekonanie - począwszy od ukazania się pionierskiej pracy Mancura Olsona The Logic of Collective Action. Public Goods and the Theory of Groups w 1965 roku - że zorganizowane wąskie interesy mają szkodliwy wpływ na dobrobyt społeczeństwa. Małe organizacje branżowe często są w stanie wywalczyć cło albo lukę podatkową, a koszt tego ponoszą miliony konsumentów i podatników.

Wzgląd na sektorowy podział biznesu pomaga uświadomić sobie, jak pewne cechy działalności gospodarczej, na przykład intensywność wykorzystania poszczególnych środków produkcji, specyficzne właściwości aktywów czy stopień koncentracji produkcji wpływają na preferencje i zdolność biznesu do zbiorowych działań, a w efekcie - na wyniki polityki gospodarczej (patrz Frieden 1991). Niektóre badania empiryczne na przykład (Shafer 1997) pokazują, że skłonność do zbiorowego działania jest tym mniejsza, im mniejsze korzyści skali w sektorze, prostsza technologia i niższe umiejętności pracowników, im mniej kapitału potrzeba, aby wejść do branży. Można postawić hipotezę, że wyniki będą lepsze tam, gdzie system polityczny zapewnia silną reprezentację tym sektorom, które stanowią o przewadze komparatywnej kraju. Tam, gdzie w wiodących sektorach są niskie bariery wejścia, małe korzyści skali, wysoka pracochłonność i duża wrażliwość na wahania rynku, rząd z większą swobodą powinien manewrować względem sektora prywatnego (Haggard, Maxfield, Schneider 1997, s. 58-59).

Nie bez znaczenia jest, z jakimi firmami państwo ma do czynienia; stopień koncentracji kapitału i stopień zdywersyfikowania dzialalności firm odgrywa rolę w stosunkach między państwem i biznesem. Patrząc na biznes z poziomu firmy można zauważyć, że szczególnie w wielu krajach „doganiających” dominuje garść wielkich konglomeratów (np. w Korei, Turcji, Meksyku i Chile). Są to grupy przemysłowe, zaangażowane w różnorodnych, często nie powiązanych ze sobą sektorach, których produkcja waży w gospodarce narodowej. Duże firmy, co potwierdzają niektóre studia przypadków (np. chaebole w Korei w latach 80., patrz Fields 1997), wykorzystują swój stosunkowo duży udział w łącznym krajowym produkcie jako argument na rzecz uprzywilejowanego traktowania. Dość

${ }^{10}$ Na przykład przeciwstawne interesy mają eksporterzy i importerzy, gdy chodzi o zmianę kursu wymiennego waluty krajowej, najmujący siłę roboczą przemysłowcy i właściciele ziemscy, gdy chodzi o ceny żywności itp. 
oczywiste konsekwencje wysokiej koncentracji kapitału dla stosunków biznesu z rządem można zilustrować na przykładzie zadłużenia. Firmy, w których udział długu w kapitale jest wysoki, są zazwyczaj bardziej skłonne stosować się do dyrektyw rządu, jeżeli ów kontroluje alokację kredytu. Jednak w przypadku wielkich firm, wysoki poziom zadłużenia zmienia układ sił na ich korzyść, dając im sposobność nawet do szantażowania rządu.

Potencjalne następstwa wielosektorowości głównych firm dla stosunków biznesu z państwem są zróżnicowane. Taka struktura biznesu rodzi więcej problemów związanych z nadzorem i regulacją, ponieważ związki między firmami w ramach konglomeratów nie są przejrzyste. I tak na przykład w Chile w późnych latach 70. właściciele zdywersyfikowanych grup przemysłowych mogli omijać regulacje banku centralnego w celu wykorzystania funduszy zgromadzonych w bankach należących do grupy na spekulacyjne inwestycje lub na finansowanie firm zależnych (patrz Ząbkowicz 2001). Pozytywny aspekt wielosektorowości firm stanowi ich słabsze związanie z pojedynczymi sektorami i partykularnymi koalicjami na rzecz podziału dochodu. Ponieważ konglomerat jest zainteresowany w wielu typach aktywności gospodarczej, jego preferencje mogą się kłócić lub mogą być niejednoznaczne, co znacznie osłabia jego zaangażowanie na rzecz konkretnej polityki przemysłowej czy określonej polityki dostosowań.

Tym samym wysoki stopień koncentracji kapitału i produkcji w przemyśle i związane z tym możliwości szantażu mogą być częściowo osłabione dzięki wielosektorowości grup przemysłowych, co wydaje się istotnym wnioskiem dla oceny stosunków między państwem i biznesem. Empiryczna analiza koncentracji i dywersyfikacji produkcji w firmach może prowadzić do zmodyfikowania pesymistycznego oglądu neoliberałów, opierającego się głównie na stosunkach siły między rządową administracją i niewielką grupą potężnych firm, które stoją za stowarzyszeniami biznesu w USA.

Prywatna własność kapitału, lobbying na rzecz interesów sektorowych, rozmiary i stopień dywersyfikacji grup przemysłowych nakładaja strukturalne ograniczenia na politykę gospodarczą rządu. Siła tego wpływu jest różna w zależności od przypadku, ponieważ wynika ze struktury biznesu w danej gospodarce: $\mathrm{z}$ udziału prywatnego sektora w tym - kapitału zagranicznego - w łącznej podaży, od wrażliwości inwestorów na politykę gospodarczą; od rozmieszczenia produkcji między sektory, a także od właściwości gałęzi produkcji, szczególnie tych reprezentujących prze- 
wagi komparatywne kraju; od stopnia koncentracji kapitału i rozproszenia działalności korporacyjnej między różne gałęzie. W zależności od tych zmiennych, państwo albo zostaje podbite przez biznes i wąskie interesy, zgodnie z przewidywaniami pokoleń liberałów, albo pokojowo współ-egzystuje lub nawet współpracuje bez uszczerbku dla wzrostu gospodarczego.

U podłoża ogólnie akceptowanych poglądów na temat organizacji biznesu leży nieufność wobec jakiegokolwiek stowarzyszania się przedsiębiorców. Dlaczego biznes się organizuje? Organizacje biznesu mają zwykle na celu poszukiwanie dochodów rentowych, co w rezultacie niekorzystnie odbija się na efektywności i na wzroście gospodarki. Takie jest główne przesłanie literatury na temat rent seeking. Zdaniem Mancura Olsona (2000) tylko względnie mała liczba firm może kontrolować się wzajemnie i karać „wolnych strzelców” (czyli tych, co próbują brać to, za co inni płaca). Stosunkowo nieliczna grupa skłonna jest ponosić koszty organizacji w odróżnieniu od wielkiej, gdzie zysk ze zbiorowego działania rozkłada się na zbyt mikroskopijne części, aby stanowić motywację do wspólnego działania. Co oznacza, że tylko wąskie interesy, podzielane przez niewielką liczbę firm są w stanie przełamać fundamentalne przeszkody do podjęcia zespołowego działania. Wielkie grupy interesu pozostają bierne, nie przejawiają chęci lub nie są zdolne do zorganizowania się, nawet jeżeli mają bardzo istotne interesy (np. imigranci, pracownicy rolni, podatnicy, konsumenci). Taka logika prowadzi zatem do wniosku, że zorganizowana część biznesu powoduje się wąskim, partykularnym interesem.

Jednak wybitni przedstawiciele szkoły publicznego wyboru sami opisują sytuacje, w których to stwierdzenie nie musi być prawdziwe. Owe warianty, inaczej niż stanowisko przedstawione wyżej, nie wydają się powszechnie znane. Olson w The Rise and Decline of Nations (1982) wskazuje, że logika zbiorowych zachowań zmienia się wraz z zakresem organizacji i tą częścią dochodu narodowego, z której członkowie organizacji korzystają. Gdyby grupy partykularnych interesów rozrosły się tak, że reprezentowałyby większość czy choćby znaczącą mniejszość społeczeństwa, perspektywa ich interesów z konieczności stałaby się szersza (encompassing) niż interes rządzący grupą czerpiącą z mniejszej części dochodu narodowego. Im większa część dochodu narodowego, z której korzysta organizacja, tym większa jej skłonność do czerpania korzyści w sposób umiarkowany, gdzie ograniczenie stanowią względy efektywności i sprawiedliwości. Olson używa metafory, która wyjaśnia zagadnienie w bardziej dosadny sposób: „Stwierdzenie, że nie dający się usunąć (stationary) bandyta ma szeroko-perspektywiczny interes, oznacza, że jest on 
wiedziony, niby niewidzialną ręką, ku ograniczeniu stopnia swojego złodziejstwa" (Olson 1997, s. 44). Grupa o szerszym interesie będzie się opowiadać za polityką bardziej zgodną z interesem ogólnym, co oznacza, że będzie przydzielać mniejszą część dochodu dla siebie i będzie dostarczać więcej dóbr publicznych niż za panowania wąskiego interesu.

Zwolennicy współpracy między rządem i biznesem w imię rozwoju gospodarczego podchwytują ideę encompassing interest. Szeroko-perspektywiczne wielosektorowe organizacje z większym prawdopodobieństwem będą popierać politykę gospodarczą sprzyjającą efektywności całej gospodarki niż organizacje ograniczone do reprezentowania tylko partykularnych interesów. W istocie, naczelna organizacja oferuje przywódcom biznesu perspektywę bardziej przypominająca punkt patrzenia państwa (patrz Nordlinger 1981). W niektórych krajach (np. w Austrii czy Szwajcarii) federacje stowarzyszeń są zdolne do rozstrzygania sporów w ramach organizacji i do mitygowania odśrodkowych nacisków ze strony stowarzyszeń branżowych. Są pomocne, prowadząc mediację interesów we własnym zakresie zamiast przekazywać kontrowersje do państwa. Takie organizacje okazały się niezbędne w prowadzeniu polityki makroekonomicznej w Meksyku i w Chile, gdzie reguła stałych negocjacji (concertaci'on) okazała się ważną częścią rozwiązywania szczegółowych problemów gospodarczych (patrz Silva 1997).

Grupy interesu nie zawsze poszukują dochodów rentowych. Argumentów na rzecz takiego stwierdzenia dostarczyli James Buchanan i Gordon Tullock, dwaj inni wybitni przedstawiciele szkoły publicznego wyboru, w swojej książce The Calculus of Consent. Logical Foundations of Constitutional Democracy. W gospodarce nadmiernie regulowanej lub cierpiącej z powodu znacznych wypaczeń polityki ekonomicznej, segmenty biznesu stają się lobbystami na rzecz ukrócenia poszukiwania dochodów rentowych. Buchanan i Tullock opisują rozwój stosunków państwo-biznes w pierwszej połowie ubiegłego stulecia jako specyficzne błędne koło. Rozrost sektora publicznego (w stosunku do sektora prywatnego) w XX wieku pobudził praktyki rent seeking, a każdy sukces jednej z koalicji na rzecz podziału dochodu prowadził do rosnącego różnicowania i dyskryminacji innych grup społeczeństwa. Ponieważ coraz więcej grup organizowało się w celu zapewnienia sobie politycznego poparcia, coraz bardziej dyskryminacyjna stawała się działalność państwa. Niemądrze jest oczekiwać, że na „szczeblu operacyjnym” grupy interesu, jednomyślnie lub niezależnie od siebie, w ramach istniejącego porządku instytucjonalnego zaczną same ograniczać swe roszczenia. Jednak, kiedy zorientują się, że 
koszty niekończącej się walki interesów są nadmierne, wszystkie mogą się porozumieć co do zmian w regułach sprawiających, że takie zachowania mają miejsce. Nadzieję na poprawę sytuacji daje zgoda grup partykularnych interesów na zmiany na „poziomie konstytucyjnym” po to, aby zmniejszyć koszty, jakie powoduje dyskryminacyjne prawodawstwo nałożone $\mathrm{z}$ biegiem czasu. $\mathrm{W}$ ten sposób $\mathrm{z}$ racjonalnego rachunku (Buchanan i Tullock finalnie nazywają go „rachunkiem zgody”) wyłoni się porządek żywo przypominający demokrację konstytucyjną jaką znamy.

Rozważania na temat organizacji biznesu Joan Nelson (1994, s. 150) podsumowuje następująco: ,,[...] grupy interesu mają janusowe oblicze. Spełniają ważne funkcje reprezentacyjne, ale mogą też być w ogóle nie reprezentatywne. Są środkiem przekazywania preferencji grupowych pod rozwagę rządu, ale ich żądania mogą rozmiękczyć sprawność rządu. Mogą edukować swoich członków i mitygować ich zachowanie, ale mogą się także radykalizować i popierać konflikty. Stanowią kanały mediacji pomiędzy wyspecjalizowanymi rządowymi agencjami i partykularnymi ekonomicznymi bądź społecznymi interesami, ale te kanały mogą ulec degeneracji w »prywatne rządy« nie podlegające publicznej kontroli i nie uginające się przed szerszymi społecznymi problemami”. Z naszego punktu widzenia ważne jest stwierdzenie, że przynajmniej niektóre organizacje biznesu może charakteryzować szeroka perspektywa w interesach (encompassing interest), zdolność do kontrolowania i mitygowania zachowań swoich członków oraz gotowość do „rachunku zgody”. Takie organizacje stwarzają przesłanki, że będą ograniczać skłonność do pogoni za dochodami rentowymi i będą bardziej zdolne do konstruktywnej samorządności. Studia nad organizacją biznesu potwierdzają, że stowarzyszenia biznesu mogą przyczynić się do polityki sprzyjającej wzrostowi gospodarczemu (Haggard, Maxfield, Schneider 1997, s. 49). Po pierwsze, naczelne organizacje biznesu mogą zmniejszyć nacisk, jaki wywierają na polityków gospodarczych grupy partykularnych interesów. Po drugie, te organizacje mogą stać się ośrodkiem samorządności w biznesie.

Wreszcie, biznes może być postrzegany jako sieć powiązań nieformalnych. Tam, gdzie koncentracja kapitału jest duża, biznes może zrezygnować $\mathrm{z}$ formalnych struktur lub po prostu je ignorować i utrzymywać kontakty bezpośrednie z rządem. Mówiąc krótko „ministrowie resortów gospodarczych i kapitaliści kontrolujący znaczną część krajowego produktu brutto mogą wszyscy usiąść przy jednym obiadowym stole" (Haggard, Maxfield, Schneider 1997, s. 49). Biznes nierzadko wywiera wpływ na rządowych biurokratów i polityków nie poprzez lobbying, ale 
dzięki wspólnemu światopoglądowi (np. dzięki edukacji na tym samym uniwersytecie), dzięki osobistym związkom (np. poprzez małżeństwa, kluby) i dzięki pełnieniu nakładających się ról (np. krzyżująca się przynależność do rad nadzorczych).

Oczekiwania, co do roli powiązań nieformalnych, nie muszą być jednoznacznie negatywne. Wprawdzie większość badań empirycznych nad amerykańską polityką czy nad klientelizmem ${ }^{11} \mathrm{w}$ krajach rozwijających się pokazuje, jak zmowa między biurokratami, politykami i ich wyborcami przedkładała wąskie interesy ponad wspólne dobro, zniekształcała zasady demokracji, odciągała środki publiczne od bardziej produktywnych zastosowań. Jednak sieć różnorodnych powiązań osobistych może być postrzegana także z pozytywnej strony. W stopniu, w którym powtarzające się współdziałanie tworzy poczucie wzajemności i zaufanie między rządem i jego partnerami z sektora prywatnego, obie strony korzystają dzięki zmniejszeniu kosztów politycznych i transakcyjnych kosztów uprawiania polityki gospodarczej. Niestety rozgraniczenie między tymi powiązaniami nieformalnymi, które sprzyjają efektywności gospodarczej i tymi, które stanowią okazję do wykorzystania dóbr publicznych do prywatnych celów pozostaje niejasne i mało rozpoznane (Haggard, Maxfield, Schneider 1997, s. 57).

Myślenie ekonomistów na temat stosunków między państwem i biznesem zostało zdominowane przez teorię poszukiwania dochodów rentowych, według której koalicje na rzecz podziału (czy to sektory, czy indywidualne firmy, organizacje biznesu czy sieci nieformalnych powiązań) z reguły przyczyniają się do obniżenia efektywności gospodarki, zabiegając o interwencję. Prace socjologów i politologów niewiele się różnią w tym względzie. Jednak rozwinięcie niehomogenicznego pojęcia biznesu i przeprowadzenie analizy w pięciu aspektach, jak wyżej, naświetla warunki, w których współdziałanie między rządem i biznesem nie musi być szkodliwe dla wzrostu gospodarczego, a nawet może go pobudzać (patrz Haggard, Maxfiels, Schneider 1997, s. 58-60):

1) stabilne reguły gry, ustanawiane przez wiarygodny dla posiadaczy kapitału rząd, ograniczają skłonność kapitału do ucieczki i pobudzają prywatne inwestycje;

11 Terminem „klientelizm” określa się spersonalizowane, nierównoprawne stosunki wymiany (jak na przykład między właścicielem ziemskim i dzierżawcą lub między politykami i urzędnikami rządowymi a ich klientelą). Sieć otaczająca Marcosa, Somozę, Mobutu posłużyła jako pierwowzór pojęcia. 
2) tam, gdzie system polityczny umożliwia reprezentację interesów tych sektorów, które decydują o przewagach komparatywnych gospodarki krajowej, wyniki gospodarcze mogą być lepsze;

3) wysoki stopień koncentracji kapitału i wynikające z tego przesunięcie siły na korzyść wielkiego biznesu ma swoją przeciwwagę, przynajmniej częściową, w wielosektorowości grup przemysłowych;

4) organizacje biznesu o pewnych cechach są zdolne do mitygowania pogoni za partykularnym branżowym interesem i do rozwijania samorządności;

5) powtarzające się kontakty i rozliczne powiązania personalne mogą tworzyć klimat zaufania między rządem i jego partnerami z sektora prywatnego, co powinno obniżyć koszty uprawiania polityki gospodarczej.

W ocenie wszystkich pięciu koncepcji biznesu pod kątem jego stosunków z rządem i wpływu na rozwój gospodarki bardzo istotne znaczenie ma oczywiście struktura i wewnętrzne procedury państwa.

Podsumowując, przeprowadzenie każdego programu ekonomicznego wymaga koalicji pomiędzy państwem i niektórymi grupami społecznymi. Właściciele kapitału zajmują wśród nich pozycję szczególną. Kształt polityki gospodarczej i jej rezultaty zależą od cech charakteryzujących uczestników procesu porozumienia w danym czasie i danym kraju oraz od stosunku sił między nimi. Skłonność stron do współpracy i kompromisu jest oprócz tego związana $\mathrm{z}$ instytucjami rządzącymi tym społeczeństwem, unikalną tradycją i historycznym doświadczeniem. Dlatego konwencjonalna mądrość, dająca się streścić w sloganie „biznes psuje państwo - państwo psuje rynek", nie powinna być przyjmowana z dobrodziejstwem inwentarza przez kraje świeżo nawrócone na rynek i demokrację. To, co w tym względzie ma do powiedzenia główny nurt ekonomii, a także - nauk politycznych i socjologii, ma charakter prohibicyjny. Liczne przykłady, chociażby te przytoczone w artykule, ukazują okoliczności, w których współpraca między państwem i biznesem bardziej służy awansowi gospodarczemu społeczeństw niż budowanie barier i zapór między nimi. 


\section{Bibliografia}

Brennan G., Buchanan J. M., The Power to Tax: Analytical Foundations of a Fiscal Constitution, Cambridge University Press, Cambridge 1980.

Buchanan J. M., Tullock G, The Calculus of Consent. Logical Foundations of Constitutional Democracy, Arbor paperbacks, The University of Michigan Press 1997 (pierwsze wydanie 1965 r., prawa autorskie z 1962 r.).

Downs A., An Economic Theory of Democracy, Harper\&Row, New York 1957.

Evans P., State Structures, Governmet-Business Relations, and Economic Transformation, w: Business and the State in Developing Countries, pod red. S. Maxfield, B. R. Schneider, Cornell University, Ithaca and London 1997.

Evolution of Interest Representation and Development of the Labour Market in Post-Socialist Countries, pod red. J. Hausner, O. K. Pedersen, K. Ronit, Cracow Academy of Economics, Cracow 1995.

Fields K., Strong States and Business Organization in Korea and Taiwan, w: Business and the State in Developing Countries, S. Haggard, S. Maxfield, B. R. Schneider, Cornell University Press, Ithaca and London 1997.

Fragile Coalitions: The Politics of Economic Adjustment, pod red. J. M. Nelson, Overseas Development Council, Washington D.C. 1989.

Frieden J. A., Debt, Development and Democracy: Modern Political Economy and Latin America, 1965-1985, Princeton University Press, Princeton 1991.

Haggard S., Maxfield S., Schneider B. R., Theories of Business and Business-State Relations, w: Business and the State in Developing Countries, pod red. S. Maxfield, B. R. Schneider, Cornell University Press, Ithaca and London 1997.

Hausner J., Strategia negocjacyjna w procesie transformacji gospodarki, w: Strategia negocjacyjna $w$ procesie transformacji gospodarki, pod red. J. Hausnera, J. Kuronia, Fundacja im. Stefana Batorego, Warszawa 1994.

Hausner J., Wojtyna A., Evolution of Interest Representation in Poland, w: Institutional Change. Theory and Empirical Findings, pod red. S. E. Sjöstrand, M. E. Sharp, Armonk, New York, London, England 1997.

Johnson Ch., MITI and the Japanese Miracle. The Growth of Industrial Policy, 1925-1975, Stanford University Press, Stanford, California 1992.

Kochanowicz J., Reforming Weak States and Deficient Bureaucracies, w: Intricate links: democratization and market reforms in Latin America and Eastern Europe, J. M. Nelson and contributors: J. Kochanowicz, K. Mizsei, O. Munoz, Transaction Publishers, New Brunswick (USA) and Oxford (UK) 1994.

Nelson J. M., Labor and Business Roles in Dual Transitions: Building Blocks or Stumbling Blocks?, w: Intricate links: democratization and market reforms in Latin America and Eastern Europe, J. M. Nelson and contributors: J. Kochanowicz, K. Mizsei, O. Munoz, Transaction Publishers, New Brunswick (USA) and Oxford (UK) 1994. 
Niskanen W. A., Bureaucracy and Representative Government, Aldine-Atherton, Chicago 1971 .

Nordlinger E. A., On the Autonomy of the Democratic State, Harvard Universtiy Press, Cambridge 1981.

Olson M., The Logic of Collective Action. Public Goods and the Theory of Groups, Harvard University Press, Cambridge Mass - London, England 1977 (prawa autorskie z 1965 r.).

Olson M., Power and Prosperity. Outgrowing Communist and Capitalist Dictatorships, Basic Books, New York 2000.

Schneider B. R., Maxfield S., Business, the State, and Economic Performance in Developing Countries, w: Business and the State in Developing Countries, pod red. S. Maxfield, B. R. Schneider, Cornell University Press, Ithaca and London 1997.

Shafer M., The Political Economy of Sectors and Sectoral Change: Korea Then and Now, w: Business and the State in Developing Countries, pod red. S. Maxfield, B. R. Schneider, Cornell University Press, Ithaca and London 1997.

Silva E., Business Elites, the State, and Economic Change in Chile, w: Business and the State in Developing Countries, pod red. S. Maxfield, B. R. Schneider, Cornell University Press, Ithaca and London 1997.

Weiss L., Hobson J. M., States and Economic Development. A Comparative Historical Analysis, Polity Press, Cambridge 1995.

Ząbkowicz A., Instytucje $i$ wzrost gospodarki w Chile, Wydawnictwo Naukowe PWN, Warszawa 2001.

\section{Summary}

The article presents an approach to government-business relations which differs from a conventional perspective. The main stream of political science as well as the mainstream economics agree that business should be separated from the government. The article reveals that the concept of „,business" is not homogenous and, accordingly, analyzes its five aspects. It shows the conditions under which collaboration between the government officials and businessmen needs not be harmful for economic growth, and may be even conducive to it. Examples in the article show that cooperation between government and business may be more beneficial than building barriers between them. 